Al-Fikra: Jurnal Ilmiah Keislaman, Vol. 5, No. 1, Januari-Juni 2006

\title{
MENUJU SISTEM PENDIDIKAN INTEGRAL MELALUI DEKONTRUKSI DIKOTOMI ILMU PENGETAHUAN
}

\author{
Masduki \\ Fakultas Dakwah dan Ilmu Komunikasi UIN Suska Riau
}

\begin{abstract}
Towards Integrated Educational System Through Dichotomy Deconstruction of Science: The development of science and technology plays a key role in developing the community which is directly related to education. However, the quality of education in Indonesia including Riau is still low. Educationalists claim that one of the factors as to why it happens is that there is a belief that there is a sort of dichotomy of general science and religious science. Through books and our everyday talks we often hear the terms general science and religious science from which other terms such as general school and religious school, general faculty and religious faculty were born. Nevertheless, it was discovered lately that this was caused not only by the dichotomy in science but also by the dichotomy in leadership and management systems. A leader sometimes does not position himself as a leader and a manager, while in managing an educational institution both leadership and managerial attitude must be planted in the manager's mind. This article tries to explore the above insight because the discourse of the dichotomy in education seems to give an image that there is a separation between general science and religious science, whereas the dichotomy in leadership and management also gives an image that there is a separation between the leader and manager.
\end{abstract}

Keywords: Education, dichotomy, Deconstruction of Science.

\section{Pendahuluan}

Saat ini, keperhatinan yang mendalam patut dirasakan bila kita melihat terjadinya dikotomi ilmu yakni antara ilmu agama dan ilmu umum. Kita mengenal bahkan meyakini adanya sistem pendidikan agama dan pendidikan umum. Kedua sistem pendidikan ini lebih dikenal dengan pendidikan tradisional untuk yang pertama dan pendidikan modern untuk yang kedua.

Seiring dengan terjadinya dikotomi tersebut, berbagai istilah yang kurang tepatpun muncul, misalnya fakultas agama dan fakultas umum, sekolah agama dan sekolah umum. Bahkan, dikotomi ini menghasilkan kesan bahwa pendidikan agama berjalan tanpa dukungan iptek dan sebaliknya pendidikan umum hadir tanpa sentuhan agama. Ironisnya, muncul fenomena memperhatinkan yakni tumbuhnya pemikiran orang, yang menyebut dirinya sebagai "orang umum" untuk tidak menyangkutpautkan ilmu pengetahuan dengan agama. Artinya mereka menginginkan penetahuan dan kajian murni (pure scince) yang sama sekali tidak boleh dipengaruhi oleh agama. Sekalipun pemikiran ini mendapat dukungan dari berbagai ahli ilmu pengetahuan, namun 
harus diakui juga bahwa ini adalah hasil dari paradigma filsafat modern, dengan pendahulunya renaissance,' yang berhasil 'mengikis habis' sisi spiritualitas wahyu dalam frameworknya. ${ }^{2}$ Lalu, kalau demikian fakta yang ada, bagaimana konsep sesungguhnya tentang ilmu pengetahuan dalam Islam? Benarkah Islam mengakui adanya dikotomi itu?, atau Islam mengakui adanya pengetahuan universal dan integral?. Mampukah Islam menemukan konsep epistimologis yang mampu mendekontruksi dikotomi tersebut dan menjembatani lahiranya system pendidikan yang terintegrasi? Jika Islam mengakui pengetahuan yang universal dan integral, maka permasalahan yang muncul berikutnya adalah mampukan para pengelola lemabaga pendidikan, sebagai seorang atau sekolompok muslim mengaktualisasikan pandagan Islam tersebut dalam dunia pendidikan sementara mereka tidak memiliki sikap kepemimpinan yang menyatu dengan kemampuan manajerial?, atau mampukan para pengelola memanaj hal itu sementara dirinya tidak memiliki jiwa memimpin?

\section{Ilmu Pengtahuan dalam Tinjauan Sejarah Islam}

Pengetahuan ilmiah orang Arab pada mulanya sangat terbatas dan secara umum bersandar pada mitologi. Orang-orang yang punya rasa ingin tahu,

1 Tidak dapat disangkal lagi bahwa perkembangan ilmu pengetahuan dan teknologi berawal dari kemunculan renaissance yang kemudian menjadi cikal bakal lahirnya filsafat modern. Tanpa kehadiran renaissance dan filsafat modern, barangkali pemikiran manusia belum mampu menemukan sumber-sumber pengetahuan. Beruntunglah sisi positif yang dimunculkan oleh renaisnace dan filsafat modern telah mampu merubah pola berfikir manusia, sehingga ilmu pengetahuan dapat berkembang bebas, karena mampu berfungsi sebagai wadah alternatif yang tepat untuk menampung tradisi berpikir bebas. Para ahli mengenal ini dengan istilah tahap-tahap perkembangan pemikiran manusia.

${ }^{2}$ Dalam tingkat aksiologi, Filsafat Barat Modern menurut Hasan Bakti Nasution, lebih ditujukan pada upaya penggambaran dunia apa adanya secara radikal dan bebas, sesuai dengan semangat inidividualisme, rasionalisme, ateisme danlain-lain, tanpa terkait dengan nilai agama yang inheren dalam kehidupan pada masanya. Bahkan dengan semangat yang cenderung tidak terkendali ada kecederungan bahwa filsafat dirahkan pada upaya pembongkaran agama (pemberontakan terhadap agama), seperti yang ditampilkan oleh berbagai aliran filsafat modern, sejak rasionalisme sampai pragmatisme. Trend ateisme (tidak lagi mempercayai Tuhan) merupakan fenomena yang muncul di dunia Barat Modern, termsuk dari kalangan ilmuan. Hal ini berbeda dengan semangat filsafat lainnya, bahwa filsafat diarahkan pada upaya penguatan agama dalam kehiduapn manusia sehingga diupayakan kehadirannya menjadi bagian inheren manusia yang tak terlepaskan. Filsafat Modern tidak hanya memunculkan aliran-aliran epistimologi, tetapi juga mengantarkan lahirnya revolusi industri di abad 18 dan negara-negara kebangsaan, serta ideologi-ideologi dunia seperti Liberalisme/Kapitalisme dan Sosialisme/Komunisme. Dengan demikian dapat dimengerti bahwa Filsafat Barat Modern adalah pemikiran yang muncul di Barat setelah abad pertengan yang bertujuan pada upaya penggambaran dunia apa adanya secara radikal dan bebas, sesuai dengan semangat inidividualisme, rasionalisme, ateisme dan lain-lain, tanpa terkait dengan nilai agama yang inheren dalam kehidupan pada masanya. Lebih lanjut lihat Hasan Bakti Nasution, Filsafat Umum, Jakarta: Gaya Media Pratama, 2001, hlm. 198 
begitu masuk Islam, tertarik atau bahkan terpesona dengan pengetahuan kuno. al-Qur'an tidak melarang penyelidikan jagad raya dan sebaliknya justeru menganjurkan kegiatan ini sebab penggunaan pengetahuan secara benar akan menghasilkan kebaikan. Itulah sebabnya para ilmuan masa awal secara terbuka mengambil pengetahuan baru ini dan menggabungkannya dalam kerangka kerja intelektual mereka. ${ }^{3}$

Mengikuti tradisi para multidisipliner Yunani, para ilmuan di dunia Islam juga melakukan kajian di semua bidang pengetahuan. Penafsiran atas pernyataan al-Qur'an untuk menyelidiki jagad raya terus mendorong penelitian mereka. Setelah menyerap karya-karya terjemahan yang berasal dari Yunani dan Persia, ilmuan-ilmuan Muslim melakukan kajian secara bebas. Konsep kebebasan intelektual ini diwariskan kepada kita (Barat) melalui Universitas Jerman yang menyebarluaskan konsep kebebasan untuk mengajar dan kebebasan untuk belajar, yang belakangan berkembang menjadi konsep modern tentang kebebasan akal manusia, seperti pada masyarakat modern. Komunitas muslim menghargai pengembangan ilmu pengetahan dan menganggapnya sebagai suatu proses yang menjadikan perbaikan ekonomi dan mobilitas sosial.

\section{Ilmu Pengetahuan dalam Pandangan Islam}

Pada awalnya, sikap Islam terhadap hubungan antara pengetahuan dan kebenaran tidak mempunyai definisi yang jelas, tetapi sejak awal beberapa premis dasar tentang pengetahuan telah muncul dalam pikiran para ulama sebagaimana ditafsirkan dalam al-Qur'an dan Hadits. Ajaran yang paling mendasar dalam bidang pemikiran ilmiah Islam adalah bahwa pengetahuan mengandung semua kebenaran dan pengetahuan. Dari sini lahir dua prinsip yakni; pertama, bahwa pengetahuan tidak termasuk rincinya, ada dalam alQur'an dan kedua, bahwa al-Qur'an dan hadis mendefinisikan lingkungan dan nilai-nilai yang inheren dalam mengembangkan ilmu pengetahuan. Kedua premis pokok inilah yang mendasari pandangan Islam bahwa semua pengetahuan akhirnya menuju kepada Tuhan. ${ }^{4}$ Dalam kenyataannya, sejarah kedua macam pengetahuan yakni pengetahuan agama dan pengetahuan umum dimasukkan ke dalam kurikulum pendidikan Islam. Ibu Khaldun, sebagaimana

${ }^{3}$ Charles Michael Stanton, Higher Learning In Islam. Penterj. H. Afandi dan Hassan Azhari. Jakarta: Logos Publishing House. 1994, hlm. 120.

${ }^{4}$ Syed Husein Nasr, Islamic Science: An Illustrated Study. London: World of Islamic Publishing, 1976, hlm. 31-36. Karena pemikiran ini, Syed Husein Nasr bagi penulis pantas mendapatkan prediket filosof perrenialisme Islam modern.Baginya, krisis intelektual, salah satunya, disebabkan oleh kebobrokan etika Barat yang mempengaruhi Islam. Karena itu dirinya berusaha mengatasi peradaban modern dengan melakukan penekanan pada rekontruksi "rancang bangun" pemikiran Islam. Lebih lanjut lihat Syed Husein Nasr, Tradsional Islam in Modern World, Kuala Lumpur: Fondations For Tradisional Studies, 1988. 
yang dikutip oleh Ahmad Tafsir, ${ }^{5}$ menyebutkannya dengan istilah pengetahuan naqliyah (diwahyukan) dan pengatahuan aqliyah (dipikirkan), sedangkan alSyaibani, ${ }^{6}$ menyebutnya dengan pengetahuan fitriyah pembawaan dan pengetahuan yang dipelajari.

Sekarang, ketika pemikiran dan keterampilan demikian maju, ketika keimanan dan pemikiran tidak sejalan, hubungan antara pengetahuan yang diwahyukan dengan pengetahuan yang diperoleh 'terganggu' sehingga muncullah keterpisahan antara keduanya. Inilah pandangan sekuler. Keterpisahan ini sebenarnya menimbulkan konflik baik dalam diri perseorangan maupun dalam masyarakat, konflik pribadi dan sosial. Oleh karena itu keterpisahan itu seharusnya diakhiri dan pengetahuan yang terpisah itu harus disatukan lagi.

Pengintegrasian kembali kedua pengetahuan itu harus dimulai dengan membangun kembali 'Filsafat Pengetahuan Islam' dan mengintegrasikan kembali sistem pendidikan umum dan agama. Orang Islam harus segera menyadari bahwa tradisi aslinya telah dikacaukan oleh tradisi Barat. Tradisi Barat memang memisahkan antara pengetahuan yang diwahyukan dan pengetahuan yang diperoleh. Oleh karena itu dalam konsep Islam ilmu pengetahuan hanya satu. Untuk kepentingan pendidikan, pengetahuan yang satu itu harus diklasifikasikan. Klasifikasi pengetahuan itu ialah pengetahuan yang diwahyukan dan pengetahuan yang diperoleh. Sedangkan klasifikasi yang ditawarkan oleh konfrensi pendidikan di King Abdul Aziz adalah perrenial knowledge dan aquired knowlwdge. Secara lengkap pengklasifikasian hasil konfrensi itu ialah:

Kelompok I.

1. Al-Qur'an; meliputi qiraah, hafalan, tafsir, sunnah, shirah (nabi, sahabat dan tabi'in) tauhid, ushul fiqh dan bahasa al-Qur'an.

2. Pengetahuan pembantu; meliputi metafisika Islam, perbandiangan agama dan kebudayaan Islam.

Kelompok II:

1. Pengantar imajenatif; meliputi arsitektur Islam dan bahasa-bahasa.

2. Pengetahuan intelektual; meliputi pengetahuan sosial yang mencakup kesusastraan, filsafat politik, pendidikan, ekonomi, geogarafi, sosiologi, linguistik, psikologi dan antropologi.

3. Pengetahuan terapan (Applied sciences); meliputi rekayasa dan teknologi, kedokteran, pertanian dan kehutanan.

4. Pengetahuan praktis; meliputi perdagangan, administarsi, perpustakaan dan komunikasi.

Kedua jenis pengetahuan di atas pada dasaranya harus diintegrasikan sebab dalam Islam ilmu teori umum harus dipandang dari kaca mata Islam. 1992.

5 Ahamd Tafsir, Ilmu Pendidikan Dalam Perspektif Islam. Bandung: Remaja Rosda Karya, 'Syaibani, Falsafah Pendidikan Islam. Jakarta: Bulan Bintang. 1979, hlm. 269 
Caranya, menurut Ahmad Tafsir, semua pengetahuan jenis kedua (yang diperoleh) harus diajarkan dengan menggunakan perspektif Islam. Itulah cara mengintegrasikan pengetahuan. Upaya integrasi kembali ilmu pengetahuan ini sebenarnya telah banyak mendapat dukungan dari para ahli (Islam), misalnya Mahdi Ghulsyani, ${ }^{7}$ yang sejak awal sangat tidak menyetujui klasifikasi ilmu agama dan non agama. Oleh karena itu pengintegrasian kembali ilmu menjadi satu adalah bahwa semua ilmu adalah ilmu Allah SWT karena datangnya dari Allah SWT. Tidak ada pengetahuan (ilmu) yang dimiliki selain apa yag diajarkan Allah SWT. Hal ini sesuai dengan Firman Allah SWT dalam alQur'an surat al-Baqarah ayat 32.

Kesatuan pengetahuan berlaku diseluruh jagad raya yaitu bahwa semua benda material dan supranatural saling berkaitan dalam satu desain induk. Hubungan antara benda ditentukan dalam satu sistem hirarki oleh kehendak Allah SWT. Pengetahuan tentang obyek apapun di dunia mesti karena hubungannya dengan obyek-obyek lain di alam dunia maupun di alam supranatural menuju Allah SWT. Dengan demikian keterlibatan seseorang dalam pengembangan pengetahuan sebenarnya merupakan pencarian mejuju Zat Ilahi. Oleh karena itu semua obyek saling terkait dan pada akhirnya menuju satu pemahaman tentang bagaimana memperoleh pengetahuan yang Universal itu. ${ }^{8}$ Secara ringkas, pandangan Islam terhadap pengetahuan dapat dijelaskan dengan asumsi bahwa pengetahuan ilmiah terkait oleh dua prinsip yakni kesatuan dan hirarki. Tidak ada wujud yang tidak berhubungan secara fisik melalui suatu hirarki yang berlandaskan agama. ${ }^{9}$

Perlu diketahui bahwa kekuatan spiritual yang diajarkan oleh Islam (alQur'an dan Hadits) membimbing manusia untuk gemar membaca dan menulis. al-Qur'an memberikan petunjuk kepada manusia terutama dalam aspek etik, historis (psikologi) dan observatif. Ketiga aspek ini merupakan alat untuk menempatkan tauhid sebagai faktor yang berperan dalam kebudayaan intelektual menusia sebagai landasan tertinggi. ${ }^{10}$

\section{Menuju Sistem Pendidikan Terintegrasi}

Ada dua cara yang sangat dibutuhkan jika kita menginginkan lahirnya pola pendidikan yang terintegrasi. Cara yang pertama menyangkut upaya mengintegasikan pengetahuan umum dan agama, dan cara yang kedua adalah mengintegrasikan sikap kepemimpinan dan manajerial dalam diri pengelola.

a. Upaya mengitegrasikan pengetahuan umum dan agama dalam satu bentuk lembaga pendidikan.

${ }^{7}$ Ghuslani, The Holy Qur'an and The Science of Nature. Penterj. Agus Efendi, Bandung: Mizan. 1993, hlm. 44

${ }^{8}$ Charles Michael Stanton, Higher Learning ..., hlm. 122

${ }^{9}$ Munir al-Din, Muslim Education. Zurich: Verlag Der Islam, 1968, hlm. 28

${ }^{10}$ Hamid Hasan al-Bigrami, The Concept of Islamic University. perterj. Machnun Hussein. Jogjakarta: Tiara Wacana, 1989, hlm. 4. 
Mengaitkan Islam dengan kategori keilmuan seperti konsep ilmu pengetahuan umumnya berhadapan dengan pengertian Islam sebagai sesuatu, yang dalam kategori Islam dapat dilihat sebagai, kekuatan iman dan takwa, sesuatu yang sudah final. Sedangkan kategori ilmu seperti disebutkan di atas, memilki ciri khas berupa perubahan perkembangan dan tidak mengenal kebenaran Absolut. Semua nilai kebenaranya bersifat relatif. Islam, yang dilihat dari sudut pengembangan ilmu pengetahuan, adalah sesuatu yang masih dalam proses, artinya masih terus menerus dicari dan dikembangkan, belajar terus tanpa henti untuk mencari dan menemukan Islam. ${ }^{11}$

Menurut catatan sejarah, filsafat dan ilmu pengetahuan serta teknologi keduanya dilahirkan dan dikembangkan pertama kali oleh bangsa Yunani dengan mendasarkan pada hukum alam (natural law). Mereka meyakini bahwa kebenaran mutlak hanya ada di alam idea. Sedangakan yang ada di dunia hanyalah bayangan dari kebenaran alam idea itu. Oleh karena itu sifatnya relatif. Para ahli Yunani sejak ribuan tahun sebelum Muhammad SAW lahir di dunia ini, sudah mengingatkan kepada seluruh ilmuan bahwa ada orde yang tidak mungkin dilampaui oleh manusia dan oleh siapapun yakni orde alam. Karena bangsa Yunani tidak mengenal agama Samawi, maka filsafat dan Ilmu pengetahuan yang dikembangkan adalah sekuler. Bahkan Universitasuniversitas modern yang berdasarkan model-model Barat tidak mencerminkan manusia, melainkan lebih mencerminkan negara sekuler. ${ }^{12}$

Masalah hukum alam, oleh sebagian orang Islam, dikembangkan menjadi sunnatullah. Kerja ini disebut dengan mengislamisasikan. Hukum alam adalah ciptaan Allah SWT dan kebenaran di alam idea menjadi kebenaran Allah SWT. Maksudnya, kebenaran mutlak yang hak itu hanya ada pada Allah SWT. Sedangkan kebenaran duniawi adalah kebenaran relatif yang harus secara menerus dikembangkan berdasarkan perspektif kebenaran Allah SWT. Dengan demikian dalam pemahaman nalar Islami, pengembangan ilmu pengetahuan tetap menggunakan metodologi keilmuannya secara intrinsik dan menjadi tuntutan universal. ${ }^{13}$

Dalam pandangan Islam, ilmu sudah terkandung secara esensial dalam alQur'an. Oleh karena itu berilmu berarti beragama dan beragama berarti berilmu, maka tidak ada dikotomi antar ilmu dan agama. Ilmu tidak bebas nilai, tetapi bebas dinilai atau dikritik, menilai dan menggugat kembali keabsahan dan kebenaran suatu pendapat adalah diharuskan tanpa menilai yang berpendapat. Bahkan, ilmuan dengan senang hati melemparkan pendapatnya untuk nilai dan bukan untuk dipertahankan, karen yang dicari adalah kebenaran bukan pembenaran. Oleh karena itu dalam Islam

${ }^{11}$ Mastuhu, Memberdayakan Sistem Pendidikan Dalam Islam. Jakarta: Logos Wacana Ilmu, 1999, hlm. 8

${ }^{12}$ Naquib Al-Attas, The Concept of Education in Islam: A Frame Work For an Islamic Piblosophy of Education, Bandung: Mizan, 1996, hlm. 84-85

${ }^{13}$ Ibid. 
diharapkan muncul intelektual yang bersif jujur, berpengalaman, randah hati dalam arti menerima kemungkinan kebenaran orang lain dan tidak mengisolir diri sehingga ilmuan Islam berbeda dan mempunyi identitas diri dengan ilmuan non muslim. ${ }^{14}$ Itulah sebabnya pandangan Barat sangat sulit untuk menampilkan sisi harmonis antar kedua variabel di atas. Barat tidak akan mampu menjembatai dikotomi tersebut karena Barat telah berkembang terlalu jauh di atas perpaduan berbagai nilai kebudayaan Yunani, Romawi Kuno dan lain-lain.

Meskipun telah berusaha bangkit kembali menemukan 'barang yang lepas' dan hal ini amat terasa sejak abad ke 19 dan awal abad 20, umat Islam tetap harus kerja keras untuk mengejar ketertinggalan apalagi era yang dihadapinya saat ini telah memasuki zaman postmodern. Rasanya, umat Islam akan tetap tertinggal jika terus berpikir reaktif dan bukan proaktif atau responsif untuk menguasai kembali ilmu pegetahuan.

Bagi Arkoun, pemikiran umat Islam belum mampu keluar dari kungkungan antara lain disebabkan oleh dominasi pertama; gambaran dogmatis dari suatu nalar yang mampu mencapai keberadan Allah, kedua; dorongan utama dari setiap penemuan tidaklah bersifat ilmiah, tetapi bersifat estetis etis, ketiga; akal yang merupakan refleksi dan inteligensi adalah ciptaan Allah dan dikuasai oleh gagasan untuk kembali kepada Pencipta Pertama dan keempat; bahwa kegiatan-kegiatan nalar menyatakan sesuatu dalam usaha kembali ke landasan-landasan agama. ${ }^{15}$

Kalau dilihat sejarah pendidikan Islam, maka muncul beberapa tokoh yang berusaha menyelesaikan dikotomi pengetahuan di atas, antara lain:

1. Sir Sayyir Ahmad Khan, dengan mendirikan AMU (Aligarh Muslim University). Dalam upaya menghancurkan dikotomi ini, ia mencontoh sistem sekolah di dunia Barat dengan memasukkan pelajaran bahasa Inggris dan Filsafat Barat ke dalam sekolah-sekolah Muslim. Sistem ini berhasil di kalangan mereka. Seusai sekolah mereka umumnya memasuki lapangan kerja di mana kemampuan bahasa Inggris dan nalar Filsafat Barat disyaratkan oleh pemerintah kolonial Inggris saat itu. Namun hal ini segera mendapat tantangan keras dari komunitas Muslim radikal yang menganggap sekolah sebagai lembaga yang berusaha mendangkalkan agama. Walaupun demikian AMU sampai kini tetap berdiri tegak

2. Maulana Abu al-Nasr Wahid dan Bengal. Beliau mewajibkan siswanya mempelajari bahasa Arab, pengetahuan agama, bahasa Inggris, aljabar dan geometri. Para siswa mengambil ujian yang sama dengan rekan-rekannya untuk memasuki universitas umum (modern). Dalam perkembangan lebih lanjut ternyata masih saja terasa adanya perbedaan antara rumpun ilmu

${ }^{14}$ Azyumardi Azra, Esei-Esei Intelektual Muslim dan Pendidikan. Jakarta: Logos Wacana Ilmu, 1998, hlm. 456.

15 Al-Arkoun, Nalar Islam dan Nalar Modern: Berbagai Tantangan dan Jalan Baru. Jakarta: INIS, 1994, hal. 81-82. 
Al-Fikra: Jurnal Ilmiah Keislaman, Vol. 5, No. 1, Januari-Juni 2006

agama dan ilmu skuler. Keduanya belum menyatu dan masih berdiri sendiri dan lama-lama perbedaannya semakin mecolok dan oleh karena itu dualisme sistem pendidikan tetap berlaku.

3. Ahmed al- Beely dari Univertas Arab Saudi. Pemikirannya adalah bahwa anak-anak muslim perlu mengambil ilmu-ilmu modern dan keagaman. Namun demikian mereka harus mempunyai landasan pendidikan agama yang kuat. Untuk itu kegiatan pendidikan harus dimulai sejak kecil (dalam keluarga) seperti shalat, baca al-Qur'an dan lain-lain. Dengan begitu, bagi mereka yang ingin mengambil spesialisasi ilmu-ilmu modern telah memiliki landasan agama yang kokoh sehingga mampu menahan gejolak skularisasi. ${ }^{16}$ Sebaliknya mereka yang akan mengambil spesialisasi ilmu keagamaan akan mampu menjelaskan ajaran agama dengan bahasa dan logika modern. ${ }^{17}$

Atas dasar ini orang-orang yang memahami peranan dan posisi ilmu-ilmu agama dalam tantangan modern, harus mampu membuat rumusan di mana ilmu-ilmu agama dapat menjawab tantangan zaman yang dihadapinya misalnya persoalan ekonomi, politik dan sebagainya, dengan melahirkan disiplin ilmu baru seperti ekonomi Islam, Politik Islam dan lain-lain. Kata-kata Islam perlu dimunculkan bukan dalam arti untuk mengislamiskasikan ilmu yang memang suadah Islami, tetapi sekedar memberi identitas kepada kedua wilayah yang sering dipertentangkan, sekalipun sebenarnya tidak bertentangan.

Oleh karena itu harus dicari 'titik temu' dan meletakkan hubungan antara kedua disiplin, yang dipahami oleh sebagian orang berbeda, dalam situasi yang lebih empirik, dengan mendudukkan sejumlah pemikir dan aktivis sosial-politik untuk membangun paradigma altenatif yang dipandang memungkinkan.

Paradigma alternatif ilmu pengetahuan yang penulis tawarkan dalam tulisan ini adalah ilmu pengetahuan yang berdasarkan filsafat theosentris dan antroposentris secara bersama-sama. Berdasarkan model ini, paradigma baru pendidikan Islam yang ingin dikembangkan adalah tidak adanya dikotomi antara ilmu pengetahuan dan agama, tidak ada dikotomi antara ilmu pengetahuan umum dan agama, ilmu tidak bebas nilai tetapi bebas dinilai,

\footnotetext{
16Proses sekularisasi yang menyeret kepada paham sekulerisme, pada mulanya tidaklah bermaksud meniadakan agama, melainkan hanya menempatkan agama sebagai 'urusan pribadi' atau paling tidak hanya sekedar 'hobi'. Dalam masyarakat sekuler, orang cenderung memecahkan masalah-masalah kehidupannya dengan tidak lagi memerlukan ajaran agama, melainkan dengan pemecahan rasional yang serba positif sebagai indikasi lahirnya sekularisme. Pandangan ini sebenarnya berawal dari sebuah generalisasi umum atas konsep sekularisasi yang termuat dalam secularization thesis. Dalam masyarakat sekuler, orang cenderung memecahkan masalah-masalah kehidupannya dengan tidak lagi memerlukan ajaran agama, melainkan dengan pemecahan rasional yang serba positif. Sain dan teknologi dijadikan institusi terakhir dalam mengatasi persoalan tanpa mengikutsertakan dimensi transendental.

${ }_{17}$ Mastuhu, Memberdayakan Sistem Pendidikan ..., 1999, hlm. 13-14.
} 
mengajarkan agama dengan bahasa ilmu pengetahuan dan tidak hanya mengajarkan sisi tradisional melainkan juga sisi rasional.

Untuk memenuhi hal di atas tawaran yang mungkin dikedepankan adalah bahwa setiap ilmuan harus mampu berfikir dan mengembangkan keilmuannnya dalam lingkup iman adan takwa. Tentu, konstruksi pemikiran yang ditawarkan harus dipengaruhi oleh pandangan-pandangan, filosofis, teologis dan sosiologis serta hal-hal yang melingkupinya. Hal ini bisa dilakukan dengan pendekatan metodologi yang baru. Metodologi yang tepat untuk hal ini adalah pengembangan metode rasional dan empirik serta memadukan aspek tradisional dan modern sesuai dengan sifat, corak dan kebutuhannya. Atas dasar ini, diharapkan muncul kesepakatan wawasan dan pandangan sebagai berikut:

1. Konsep pendidikan skuler tidak sepenuhnya tidak cocok dengan ajaran Islam. Ia mengandung beberapa beberapa kebenaran terutama yang berkenaan dengan perkembangan teknolgi yang dapat diterima oleh Islam.

2. Islam tetap menghormati dan menerima konsep pendidikan tradisional yang sudah mengakar atau mentradisi dalam kehidupan umat Islam. Namun demikian harus sadar adanya hal-hal yang perlu ditinggalkan karena sudah tidak cocok lagi dengan perkembangan zaman.

3. Pendidikan Islam harus mengajarkan ilmu pengetahun mulai hal-hal dini atau kebiasan positif, dari pola pendidikan tradisional dan mengembangkannya sesuai dengan perkembangan pemikiran dan dengan menggunakan konsep pendidikan modern setelah mengislamkannya terlebih dahulu dari bagian-bagian tertentu, sehingga perkembangannya benar dan sesuai dengan ajaran Islam.

4. Generasi muda Islam perlu belajar sampai ke tingkat spesialisasi, baik ilmu keagamaan maupun ilmu skuler, namun mereka harus memiliki dasar agama yang kuat sebelum mereka memasuki jenjang spesialisasi.

Untuk mewujudkan obsesi dan kesepakatan wawasan di atas, menurut penulis semua mata pelajaran baik agama maupun umum harus diberikan dan dipahami sebagai satu kesatuan ilmu kepada siswa atau mahasiswa serta dibutuhkan wadah atau perguruan tinggi yang mampu menjembatani hal ini. Barangkali lahirnya Universitas Islam Negeri, sekolah-sekolah terpadu yang memang memadukan antara pelajaran umum dan agama, adalah jawaban atas semua kepentingan ini, tetapi semuanya terpulang kepada kurikulum yang ada. Sudah representatifkah kurikulum yang diajarkan? dan sudah representatifkah tenaga pengajar yang memiliki kemampuan mengajarkan pengetahuan umum sekaligus mampu mengaitkannya dengan agama? serta sudah lahirkah bukubuku umum yang diberi analisis agama? Mudah-mudahan semuanya sudah terwujud atau sedang menuju ke arah itu.

b. Upaya mengitegrasikan kemampuan kepemimpinan dan manajerial dalam diri pengelola 
Selain dikotomi ilmu pengetahuan umum dan agama, dikotomi terjadi pula pada diri atau kelompok pengelola. Tidak jarang orang yang memiliki kemampuan kepemimpinan tetapi mereka tidak mempunyai kemampuan manajerial, sebalilknya banyak orang yang memilki kemampuan manajerial tetapi tidak memiliki kemampuan kepemimpinan.

Apa dan siapakah pemimpin dan manajer lembaga pendidikan?. Petanyaan inilah yang sering muncul ketika penulis mencermati lahirnya Universitas Islam dan sekolah-sekolah "terpadu”. Pada tingkat pendidikan dasar dan menengah, Andrias Harefa menyebutkan bahwa kepala sekolah adalah sebuah jabatan (a position) struktural sekaligus juga sebuah pekerjaan ( $a$ job) sekolah. Dalam arti jabatan yang selalu bersifat formal, maka kepala sekolah adalah manajer sekolah. Peran, tugas dan tanggung jawabnya berkaitan dengan soal-soal menajemen. Sedangkan jika dilihat dari kacamata kepemimipinan, maka kepala sekolah adalah pemimpin dan kepemimpinan selalu mulai dengan sifat informalnya. ${ }^{18}$

Seorang pimpinan lembaga di perguruan tinggi, rektor misalnya, memainkan dua peran penting, pemimpin dan manajer. Peranannya sebagai pemimpin berhubungan dengan konsituen yakni orang-orang yang dipimpinnya dan orang-orang yang berada pada lingkar pengaruhnya meski belum tentu bawahannya. Di sisi lain pimpinan juga berperan sebagai manajer yang mengelola segala sesuatu yang ada di lembaganya, tetapi bukan orang (things but not people). Peranan sebagai manajer ini berkaitan dengan sarana dan prasarana lembaga pendidikan, sistem dan struktur yang ada dan sebagainya.

Dalam perannya sebagai pemimpin, yang menjadi fokus kepemimpinannya adalah kesadaran bahwa lembaga pendidikan harus berfungsi sebagai lembaga pengajaran (formal) yang diharapkan ikut berperan aktif dalam proses pendidikan (informal), karena itu tujuan perguruan tinggi hendaknya mencerdaskan sekaligus memanusiawikan manusia muda yang sedang berproses menjadi manusia dewasa dan mandiri. Fokus manusiamanusia di perguruan tinggi inilah yang berhubungan dengan peranan kepemimpinan instutusi pendidikan.

Dalam perannya sebagai manajer, upaya mencerdaskan sekaligus memanusiawikan manusia muda itu memerlukan sarana dan prasarana (ruang belajar, perpustakaan, laboratorium dan perlengkapan belajar lainnya). Tidak dapat dibayangkan bagaimana mungkin muncul produk-produk dari sebuah perguruan tinggi yang handal sementara sarana pendukung tidak optimal, atau sekalipun ada tetapi tidak diberdayakan atau dimaksimalkan pendayagunaanya. Fokus yang berhubungan dengan hal-hal optimalisasi dan maksimalisasi benda inilah yang berhubungan dengan peranan manajemen pimpinan lembaga pendidikan..

Pemikiran Andrias Harefa, yang sebenarnya diarahkan pada lembaga pendidikan sekolah dasar dan menengah nampaknya patut juga dipakai pada

18 Andrias Harefa, "Pembelajaran”, Jakarta: Kompas, 2001, hlm. 106. 
lembaga perguruan tinggi, sebab pemikiran ini menggiring kita untuk memahami bahwa pendidikan integral juga berkaiaan erat dengan menyatunya antara pemimpin dan manajer pada diri seorang pengelola atau kelompom pengelola lembaga. Dengan demikian dapat dimengerti bahwa dari segi fungsinya, pimpinan lembaga pendidikan tidak hanya bertanggung jawab atas kelancaran jalannya proses pendidikan secara teknis akademis atau proses belajar mengajar, akan tetapi juga segala kegiatan, keadaan lingkungan lembaga/institusi dengan kondisi dan situasinya serta hubungan dengan masyarakat sekitar (Tri Darma Perguruan Tinggi).

Selain pengelola lembaga pendidikan, para tenaga pengajarnya juga harus memiliki kemampuan ganda, yakni menguasai pengetahuan yang sifatnya umum tetapi mampu mewarnainya dengan nuansa-nuansa keislaman. Dengan kata lain, warna-warni nilai-nilai keislaman ada pada diri seorang tenaga pengajar. Ini bukan merupakan upaya Islamisasi dan pengaburan spesialisasi, karena bagi penulis semua jenis mengetahuan bermuara pada Allah SW'T (Teosentris) dan kita dianjurkan memiliki spesialissasi, tetapi lebih merupakan aplikasi dan aktualiasasi Islam dalam tata pendidikan.

Atas dasar ini, inovasi dan kreatifitas yang mengarah kepada pengembangan lembaga, baik akademis maupu sarana fisik, merupakan tugas dan tanggung jawab pimpinan. Namun demikian, dalam usaha memajukan lembaga pendidikan dan menanggulangi kesulitan yang dialami lembaga baik yang bersifat fisik seperti perbaikan gedung, penambahan ruang, penambahan perlengkapan dan sebagainya maupun yang bersifat non fisik seperti porses pendidikan, pimpinan lembaga tidak dapat bekerja sendiri. Pimpinan harus bekerja sama dengan instansi terkait seperti dunia perguruan tinggi mitra, dunia perbankan nasional maupun internasional, Pemda Tk. I dan II, Persatuan Orangtua Mahasiswa dan lembaga-lembaga pemerintah dan swasta.

\section{Penutup}

Jika kita cermati dengan seksama, dapat dimengerti bahwa saat ini ilmuilmu agama sedang mengalami tantangan yang sangat berat. Terjadinya dikotomi pengetahuan sebagaimana yang ada di Indonesia bagi penulis merupakan hasil kekurangcermatan para pendahulu atau printis pendidikan yang tidak mampu menjadikan pesantren sebagai basis lahirnya pendidikan nasional. Sekolah Belanda yang kemudian menjiawi lahirnya pendidikan nasional adalah warisan sekuler yang dengan sengaja memisahkan masalah keagamaan dengan pengetahuan modern yang melahirkan pemisahan pengetahan agama dan modern.

Saat ini dikotomi itu harus dihilangkan dengan dua cara. Pertama Mengintegrasikan pengetahuan umum dan pengetahuan agama dalam satu bentuk pelajaran (kurikulum) dan juga lembaga/institusi. Kedua Mengintegrasikan pemimpin dan manajer dalam satu diri pengelola atau kelompok pengelola subuah lembaga pendidikan. Sekarang, ketika pemikiran 
Al-Fikra: Jurnal Ilmiah Keislaman, Vol. 5, No. 1, Januari-Juni 2006

dan keterampilan demikian maju, ketika keimanan dan pemikiran tidak sejalan, hubungan antara pengetahuan yang diwahyukan dengan pengetahuan yang diperoleh 'terganggu' sehingga muncullah keterpisahan antara keduanya. Inilah pandangan sekuler. Keterpisahan ini sebenarnya menimbulkan konflik baik dalam diri perseorangan maupun dalam masyarakat. Oleh karena itu keterpisahan itu seharusnya diakhiri dan pengetahuan yang terpisah itu harus disatukan lagi. Pengintegrasian kembali kedua pengetahuan itu harus dimulai dengan membangun kembali 'Filsafat Pengetahuan Islam' dan mengintegrasikan kembali sistem pendidikan umum dan agama. Orang Islam harus segera menyadari bahwa tradisi aslinya telah dikacaukan oleh tradisi Barat. Tradisi Barat memang memisahkan antara pengetahuan yang diwahyukan dan pengetahuan yang diperoleh. Oleh karena itu dalam konsep Islam ilmu pengetahuan hanya satu. Dengan cara integrasilisasi di atas diharapkan generasi muda memperoleh pendidikan ilmu pengetahuan secara utuh baik ilmu agama maupun ilmu umum dan mereka juga memiliki kemampuan kepemimpinan dan manajerial secara utuh pula.

Seorang atau sekelompok pimpinan lembaga pendidikan harus memiliki pengetahuan dan teori-teori kepemimpinan dan manajerial sekaligus, sehingga dapat diterapkan dalam praktek kerjanya. Kepemimpinan lembaga pendidikan adalah suatu kemampuan dan proses mempengaruhi, membimbing, mengkordinir dan menggerakkan orang lain yang ada hubungannya dengan perkembangan Universitas agar lebih efektif untuk mencapai visi dan misinya. Selain itu pimpinan juga harus memiliki kemampuan manajerial mengatur efisiensi segala yang berkaitan dengan fasilitas pendidikan untuk menunjang proses belajar mengajar di Perguruan Tinggi sehingga tujuan institusi akan tercapai.

\section{Bibliografi}

Azra, Azyumardi, Esei-Esei Intelektual Muslim dan Pendidikan. (Jakarta: Logos Wacana Ilmu, 1998)

Arkoun, Nalar Islam dan Nalar Modern: Berbagai Tantangan dan Jalan Baru. (Jakarta: INIS, 1994)

Al-Attas, Naquib, The Concept of Education in Islam: A Frame Work For an Islamic Piblosophy of Education, (Bandung: Mizan, 1996)

al-Bigrami, Hamid Hasan, The Concept of Islamic University. perterj. Machnun Hussein. (Jogjakarta: Tiara Wacana, 1989)

al-Din, Munir, Muslim Education. (Zurich: Verlag Der Islam, 1968)

Harefa, Andrias, "Pembelajaran”, (Jakarta: Kompas, 2001)

Mastuhu, Memberdayakan Sistem Pendidikan Dalam Islam. (Jakarta: Logos Wacana Ilmu, 1999) 
Al-Fikra: Jurnal Ilmiah Keislaman, Vol. 5, No. 1, Januari-Juni 2006

Nasr, Syed Husein, Islamic Science: An Illustrated Study. (London: World of Islamic Publishing, 1976)

Tradsional Islam in Modern World, (Kuala Lumpur: Fondations For Tradisional Studies, 1988).

Nasution, Hasan Bakti, Filsafat Umum, (Jakarta: Gaya Media Pratama, 2001)

Stanton, Charles Michael, Higher Learning In Islam. Penterj. H. Afandi dan Hassan Azhari. (Jakarta: Logos Publishing House. 1994)

Syaibani, Falsafah Pendidikan Islam. (Jakarta: Bulan Bintang. 1979) Ghuslani, The Holy Qur'an and The Science of Nature. Penterj. Agus Efendi, (Bandung: Mizan. 1993)

Tafsir, Ahmad, Ilmu Pendidikan Dalam Perspektif Islam. (Bandung: Remaja Rosda Karya, 1992). 